\title{
後発医薬品の適正使用と医薬品添加物に関する研究
}

\author{
加藤 洋 美, 吉井美智子, 小澤光一郎*
}

\section{Comparative Study of Drug Efficacy and Drug Additives between Generic Drugs and Original Drugs}

\author{
Hiromi Katoh, Michiko YoshiI, and Koichiro OzawA* \\ Division of Clinical Pharmacotherapeutics Programs for Applied Biomedicine, Graduate School of Biomedical \\ Sciences, Hiroshima University, 1-2-3 Kasumi, Minami-Ku, Hiroshima 734-8553, Japan
}

(Received April 2, 2007; Accepted August 23, 2007)

\begin{abstract}
In the present study, we tested three kinds of sleeping drugs, consisting mainly of triazolam, brotizolam, and flunitrazepam, to compare the drug efficacy of generic drugs with that of original drugs. After these drugs were administered orally to mice, drug efficacy was evaluated in terms of ambulation, onset time of sleep, and duration of sleep in the open field test. For all kinds of sleep-inducing drugs, the drug efficacy of most generic drugs is not necessarily equal to that of the original drug. The main reason for the difference appears to be due to differences in the rate of absorption of the main drug. Any other differences between an original drug and a generic drug are caused by drug additives, the crystal form of the main drug, the formulation, and so on. In this study, the formulation was not the reason for the differences because all of the drugs were pulverized in a mortar and had no special coating. The drug additives for all the drugs are listed and the drug efficacy compared. Unfortunately, the information was not sufficient to shed any light on the differences in drug efficacy. For effective drug therapy, more information on drug additives should be provided.
\end{abstract}

Key words_ - generic drug; original drug; drug efficacy; drug additive

\section{緒言}

近年，国民医療保険は急速に進む少子高齢化によ つて増え続け，国民皆保険制度は破綻が懸念されて おり，この事態の改善策の 1 つとして, 2002 年 4 月 1 日，医療費の削減のために薬価の安い後発医薬 品使用促進政策が採られた.

後発医薬品の承認は, 1997 年以前は安定性試験 と, 健常人による生物学的同等性試験であったが, 1997 年に厚生省により「後発品の生物学的同等性 試験ガイドライン」が出され, 後発品の生物学的同 等性試験が改訂され，標準製剂と試験製剤の明確 化, 溶出試験の追加がなされた。この改正に伴い, 1997 年以前に承認された医薬品に対しても, 溶出 試験による品質再評価が始まり，結果は医療用医薬 品品質情報集(オレンジブック)で公表されている. 当初は，2004 年に終了する予定であったが，2005

広島大学大学院医歯薬学総合研究科治療薬効学研究室

*e-mail: ozawak@hiroshima-u.ac.jp
年 10 月現在で, 対象 857 成分中, 結果通知に至つ たものは 459 成分であり, 残り 398 成分は結果が通 知されていない。 そのうち半数以上が, 難溶性物 質, 分解性物質, 吸着性物質, 定量法に問題のある 物質, 溶質規格の設定に問題のある物質, 体内で吸 収されない物質, 経時変化を起こす物質等, 溶質試 験規格の設定などの技術的な問題があり，2007 年 現在もまだ進行中である.

このように品質の均等化のための試験が施行され ているが, 研究所や病院等から先発医薬品と後発医 薬品で溶出性が異なるという報告がなされ，ロキソ プロフェンナトリウム, シメチジン , ${ }^{1)}$ セファクロ ル，グリベンクラミド，テオフィリン22等の溶出試 験による医薬品の品質調査では，いくつかの後発医 薬品に関しては同等性を確保できないという結果が 報告されている。 2003 年 9 月 16 日付の「日刊薬業」 で, 後発品の使用実態・意識調査に関して, 全国保 険医団体連合会が会員医師に行ったアンケートの結 果が出ており (4892人中 2063 人が回答)，「過去 5 
年間に，先発品と異なる薬効を経験したか」という 質問に，14.4\%の人が「経験した」と回答している. また, 「過去 5 年間に先発品と異なる副作用を経験 したか」という質問には，4.5\%が「経験した」と なっている. ${ }^{3)}$

また，先発医薬品と後発医薬品の有効成分は同一 であるが，先発医薬品の製剤情報は完全には公開さ れないために，製剤を構成する医薬品添加物の種類 や量，製剤技術はかならずしも同じであるとは限ら ない．このことがバイオアベイラビリティを変化さ せ，その結果，有効性や安全性に違いを生じる可能 性がある.

これらのことから, 先発医薬品と後発医薬品の同 等性について検討する必要が考えられるため, 催眠

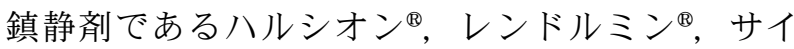

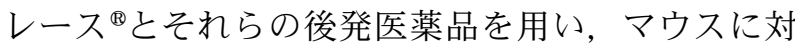
する催眠作用の比較及び主成分含有量と血中濃度を 比較検討した。

\section{実 験 方 法}

\section{1. 試薬および薬剤}

1-1. Triazolam 含有薬剤（溶出試験による品質 再評価は，すべて終了）先発医薬品 ハルシオ ン ${ }^{\circledR} 0.25 \mathrm{mg}$ 錠（ファイザー）, 後発医薬品 $\mathrm{A}-\mathrm{G}$.

1-2. Brotizolam 含有薬剂（品質再評価はすべて 終了）先発医薬品レンドルミン錠 $0.25 \mathrm{mg}$ (日本ベーリンガーインゲルハイム), 後発医薬品 $\mathrm{H}-\mathrm{T}$.

1-3. Flunitrazepam 含有薬剤（品質再評価は 2007 年 7 月現在ステップ 4) 先発医薬品 サイ レース ${ }^{\circledR}$ 錠 $2 \mathrm{mg}$ (エーザイ), 後発医薬品 U-W.

1-4. その他の試薬 Carboxymethyl cellulose sodium salt (SIGMA), Acetonitrile (nakalai tesque), $\mathrm{NaH}_{2} \mathrm{PO}_{4}, \quad \mathrm{H}_{3} \mathrm{PO}_{4}$ (関東化学), triethylamine (Aldrich).

1-5. 機器 HPLC ポンプ: HITACHI pump L-7100, UV 検出器: ShimadzuSPD-6A, カラム : Chromolith RP-18e $(100 \times 4.6 \mathrm{~mm})$ (Merck).

2. 先発医薬品之後発医薬品の薬効差の検討

2-1. 実験動物及び投与方法＼cjkstart実験動物には 57 週齢の雄性 $d d Y$ 系マウスを各群 3-5 匹用いた. 薬剂は腸溶錠等特殊コーティングが施されていない 錠剤を選択し，各先発医薬品と各後発医薬品を用い
た。各投与薬剤を乳鉢で微粉砕後， $1 \% \mathrm{CMC} \mathrm{(car-}$ boxymethylcellulose sodium salt）に懸濁させ，ゾン デを用いてマウスに経口投与した（triazolam 1.0 $\mathrm{mg} / \mathrm{kg}$, ${ }^{4)}$ brotizolam $0.75 \mathrm{mg} / \mathrm{kg}$, ${ }^{5)}$ flunitrazepam 1.0 $\left.\mathrm{mg} / \mathrm{kg}^{6}\right)$ : 投与量は $10 \mathrm{ml} / \mathrm{kg}$ に固定)。また，コン トロールには $1 \% \mathrm{CMC}$ を投与した. ${ }^{4)}$

薬効差として催眠作用の観察を行うため，一定時 間照明 (8：00-20：00) で飼育したマウスを用いた。 実験開始時間は $11 ： 00$ とし，観察時間は 11：00$17 ： 00$ の 6 時間とした.

また，投与薬物は二重盲検によって選択されてお り，実験者以外の者が薬物を選び，投与する実験者 は何の薬物を投与しているか分からないように設定 した。

\section{2-2. 観察方法}

2-2-1. 自発運動活性 オープンフィールド試 験: open field test ${ }^{7)}$

- 区画移動数：ambulation $6 \mathrm{~cm} \times 5 \mathrm{~cm}$ の升目 の付いた $30 \mathrm{~cm} \times 40 \mathrm{~cm}$ の底面と高さ $40 \mathrm{~cm}$ の オープンフィールド試験装置（Fig. 1）にマウ スを入れ， $1 \mathrm{~m}$ の直上から $100 \mathrm{~W}$ のライトを 照らし，ビデオ撮影を行い，底面の区画線を 横切る回数を測定した.

\section{2-2-2. 睡眠 : sleep ${ }^{8}$}

-睡眠導入時間 : onset time of sleep 薬剤（又は $1 \% \mathrm{CMC}$ ) を投与してから睡眠に入るまでの 時間を測定した。

-睡眠持続時間：duration of sleep 睡眠に入つ

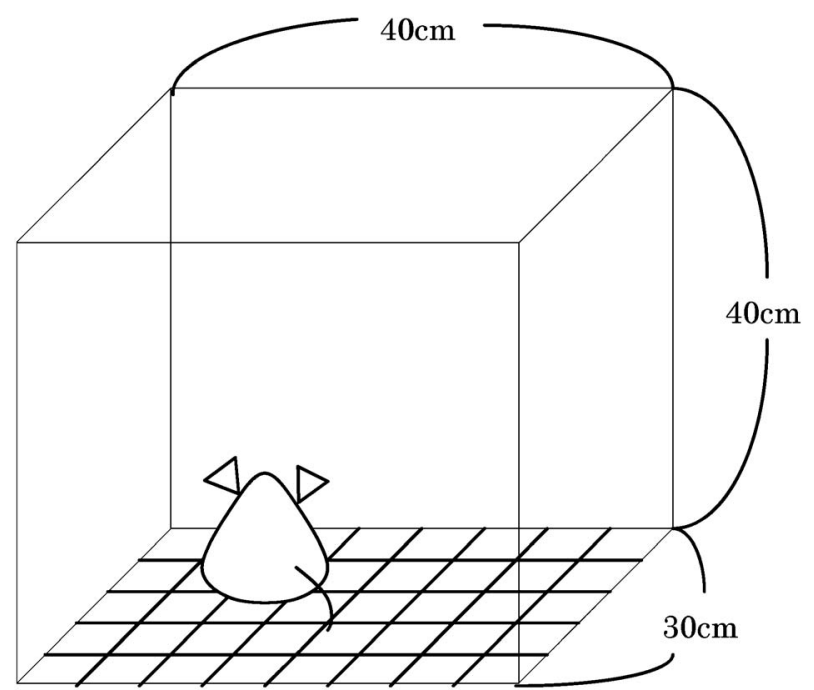

Fig. 1. Open Field Test Equipment 
てから目を覚ますまでの時間を測定した．

\section{3. 投与 1 時間後の血中濃度 実験動物には} 5-7 週齢の雄性 ddY 系マウスを各群 3 匹用いた. 薬剂投与は 2 項の薬効差の検討と同様に行い，投与 1 時間後，マウスをエーテル麻酔下に，心臓血を採 取した。採取した血液を $9000 \mathrm{rpm}$ で 10 分間遠心 し，血清を採取した。サンプルの前処理は Scheme 1 に示す方法で行った. ${ }^{9}$

\section{3-1. HPLC の条件}

・移動相： $\mathrm{H}_{3} \mathrm{PO}_{4}$ を加え $\mathrm{pH} 2.4$ に調整した 20 $\mathrm{mM} \mathrm{NaH}_{2} \mathrm{PO}_{4}$ : triethylamine $(57: 0.02)$ にア セトニトリルを加えアセトニトリル濃度 $20 \%$ から $30.5 \%(0-15 \mathrm{~min}) ， 30.5 \%$ から $36.5 \%$ （15-60 min）の濃度勾配溶出を行った.

- 流速 $: 0.5 \mathrm{ml} / \mathrm{min}$.

-内部標準物質 : Diazepam $(0.144 \mu \mathrm{g} / \mathrm{ml})$.

- 測定波長：Triazolam 含有薬剤 $(226 \mathrm{~nm})$, Brotizolam 含有薬剤 $(240 \mathrm{~nm})$, Flunitrazepam 含有薬剂 $(222 \mathrm{~nm})$.

\section{4. 各薬剤の主成分含有量の確認 2, 3 項の実} 験で用いた錠剂と同じロットの各錠剂（triazolam $0.25 \mathrm{mg}$ 錠, brotizolam $0.25 \mathrm{mg}$ 錠, flunitrazepam $2 \mathrm{mg}$ 錠の先発医薬品と後発医薬品） 1 錠を乳鉢で

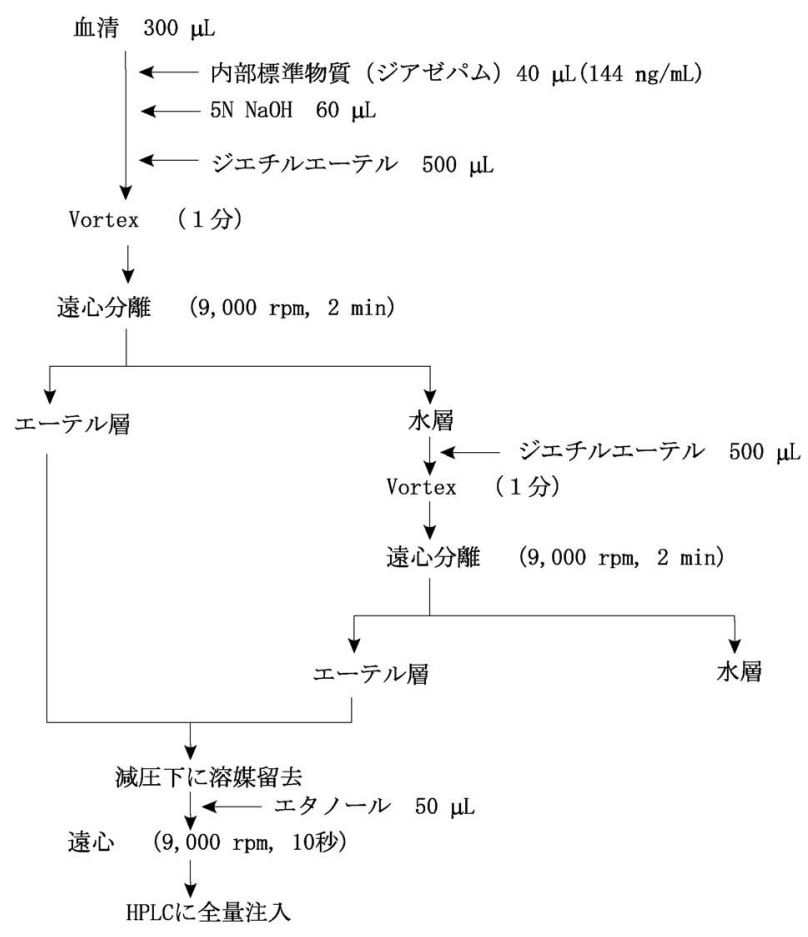

Scheme 1. Preparation of HPLC Sample
粉砕後, $2.0 \mathrm{ml}$ メ夕ノールを加え懸濁し， 30 分超 音波処理を行った。 Triazolam, brotizolam は 1/20 に希釈，flunitrazepamは1/200に希釈し，それぞ れに内部標準物質として diazepam $(12 \mu \mathrm{g} / \mathrm{ml})$ を 加え, HPLCにて主成分の含有量を測定した.

移動相：38\%アセトニトリル/ $\left(20 \mathrm{mM} \mathrm{NaH}_{2}\right.$ $\mathrm{PO}_{4}$ ：トリエチルアミン $\left.(100: 0.035) \mathrm{pH} 2.4\right)$, 流 速 : $0.6 \mathrm{ml} / \mathrm{min}$, 波長 : $230 \mathrm{~nm}$.

5. 統計解析 結果はすべて平均 \pm S.E. で表し た。統計処理には統計解析ソフト StatView5.0. (SAS Institute Inc., USA）を用い，分散分析を行つ たのち Fisher's PLSD 検定を行い, $p<0.05$ を有意 差ありとした。

\section{結果}

\section{Triazolam 含有薬剤}

1-1. 薬効の比較 薬効は, 自発運動停止によ る睡眠の開始と持続時間，また，単位時間当たりの 区画移動数による自発運動の変化を指標とした.

Figure 2(A)より，ハルシオン ${ }^{\circledR}$ (先発医薬品）と 比較し, 後発医薬品 $\mathrm{A}$ において有意に睡眠導入の 遅延が認められ，また後発医薬品 $\mathrm{E} に$ 関しては, 睡眠導入時間が有意に早かつた。睡眠持続時間につ いては, 先発医薬品と比較して後発医薬品 $D, G$ は 有意に睡眠時間の短縮がみられた。また，後発医薬 品 $\mathrm{E}$ は 2 例において睡眠を起こさなかった。

区画移動数の結果（投与直後-投与 6 時間後）は Fig. 2(B) に示した. Figure 2(A) とほぼ同様な結果 であるが，睡眠持続時間の短い後発医薬品 D, E, G に関しては，観察時間を通して他の製品に比べ薬効 が悪く，自発運動が完全には消失しなかった。 E で は自発運動が消失しないマウスが 2 匹存在していた.

1-2. 投与後 1 時間の血中濃度の比較 先発医 薬品と後発医薬品 $(A-G)$ 投与 1 時間後の血中濃 度の結果を Fig. 2 (C) に示した。先発医薬品の血中 濃度を $100 \%$ で表したときの後発医薬品（A-G）の 血中濃度を比で表した。後発医薬品 $\mathrm{E}$ は 196\%（ $p$ <0.05）と有意に血中濃度が高值を示した。また， 後発医薬品 $\mathrm{A}$ は $68 \%$ と先発医薬品と比較して血中 濃度が低い傾向が認められた。

1-3. 主成分含有量の比較 Triazolam $0.25 \mathrm{mg}$ 錠の先発医薬品と後発医薬品 $(A-G)$ の主成分含 有量を測定し，先発医薬品の主成分含有量を $100 \%$ 
(A) Onset time and duration of sleep

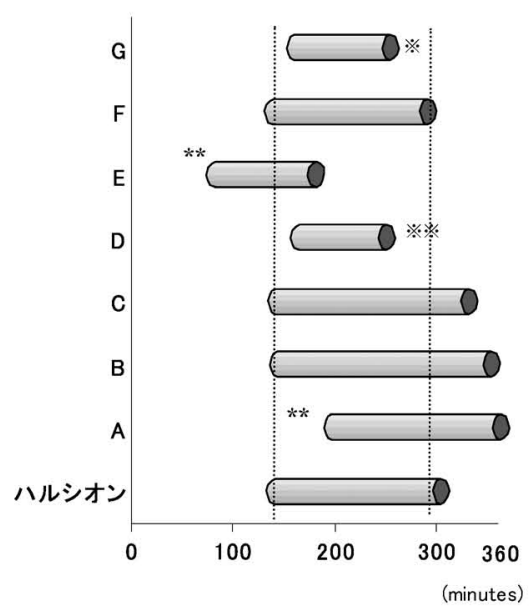

(B) Ambulation

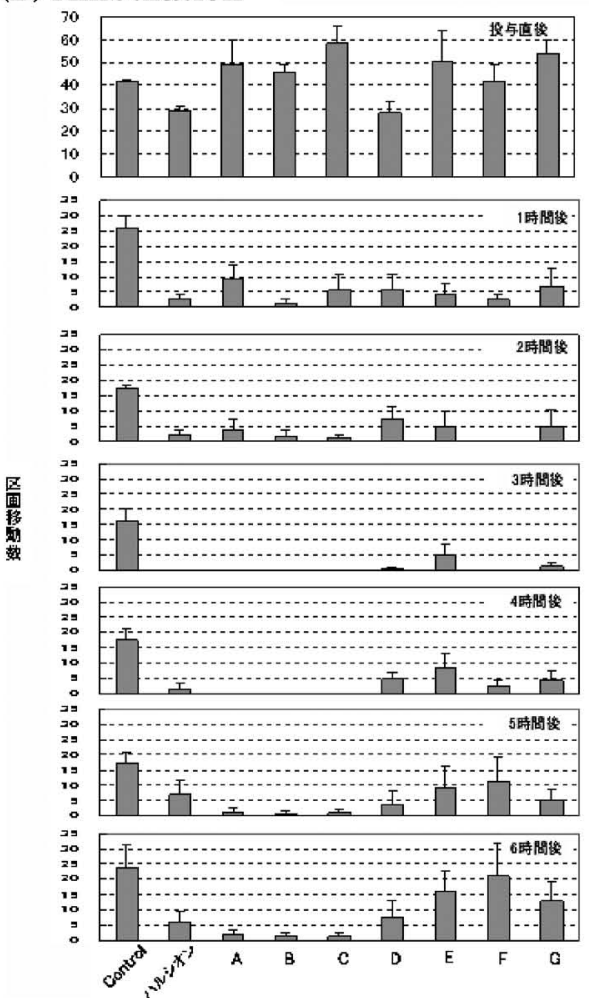

\begin{tabular}{|l|c|c|}
\hline & $\begin{array}{c}\text { 睡眠導入時間 } \\
\text { (minutes) }\end{array}$ & $\begin{array}{c}\text { 睡眠持続時間 } \\
\text { (minutes) }\end{array}$ \\
\hline $\begin{array}{l}\text { ハルシオン } \\
\text { (® }(\mathrm{n}=4)\end{array}$ & $120.8 \pm 1.7$ & $162.3 \pm 26.9$ \\
\hline $\mathrm{A}(\mathrm{n}=5)$ & $177.0 \pm 17.9^{* *}$ & $164.8 \pm 22.5$ \\
\hline $\mathrm{B}(\mathrm{n}=4)$ & $123.3 \pm 16.3$ & $209.3 \pm 27.9$ \\
\hline $\mathrm{C}(\mathrm{n}=4)$ & $121.5 \pm 11.8$ & $188.8 \pm 12.7$ \\
\hline $\mathrm{D}(\mathrm{n}=4)$ & $145.0 \pm 9.5$ & $84.5 \pm 22.3 * *$ \\
\hline $\mathrm{E}(\mathrm{n}=4)$ & $62.5 \pm 2.0 * *$ & $98.5 \pm 10.2$ \\
\hline $\mathrm{F}(\mathrm{n}=4)$ & $118.8 \pm 12.0$ & $151.3 \pm 11.6$ \\
\hline $\mathrm{G}(\mathrm{n}=4)$ & $139.8 \pm 16.6$ & $93.8 \pm 12.3 *$ \\
\hline
\end{tabular}

(C) Serum concentration

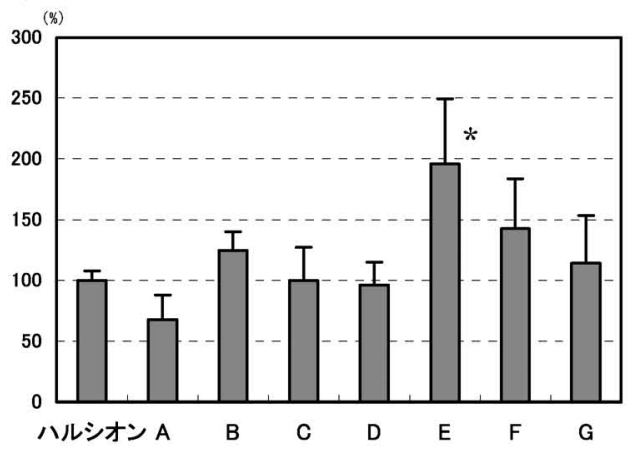

(D) Triazolam content

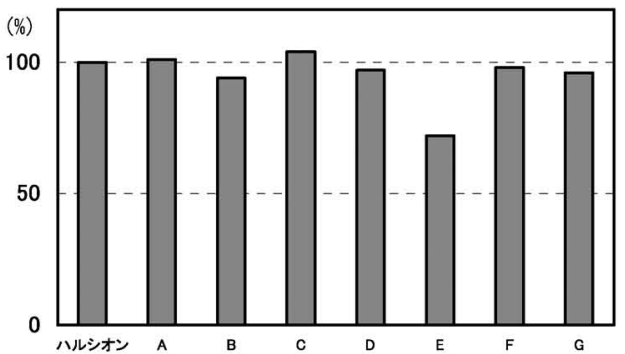

Fig. 2. Experimental Results of Triazolam Containing Drugs

A) : Comparison of onset time of sleep and duration of sleep induced with original or generic drugs containing triazolam mainly. The graph's bar means onset time of sleep after oral administration and the length means duration of sleeps. These results were shown as mean. Results in the table are expressed as means \pm S.E. ** ※※: Significantly different from ハルシオン ${ }^{\circledR}$ group $(p<0.01)$. : Significantly different from ハルシオン®group $(p<0.05)$. $(2$ mice in group E did not sleep). B) : Ambulation after administration of triazolam containing drugs. Results are expressed as means \pm S.E. C): Serum concentration of triazolam 1 hour after administration of original or generic drugs. Results are expressed as means \pm S.E. of three mice. * Significantly different from ハルシオン ${ }^{\circledR}$ group $(p<0.05)$. D) : Comparison of triazolam content between original and generic drugs.

で表したときの後発医薬品 $(\mathrm{A}-\mathrm{G})$ の主成分含有 量を比で示した (Fig. 2(D)). 後発医薬品 $\mathrm{E}$ 以外 は先発医薬品と差はみられなかったが，規格内での ばらつきを考慮に入れても後発医薬品 E は $72 \%$
と, 先発医薬品と比較して若干低含有量であった.

これらの結果から, Triazolam 含有薬剤の後発医 薬品には, 先発医薬品と薬効がほぼ同じ製品, 若干 強い製品，悪い製品が存在しており，その結果は血 
中濃度を反映していた。後発医薬品 $\mathrm{E}$ に関して は，その薬効のばらつきや血中濃度の高さ，含有量 の低さから, 含有量の差, 若しくは添加物による溶 解度及び吸収率の差が存在する可能性が示唆された。

\section{Brotizolam 含有薬剂}

2-1. 薬効の比較 Figure 3(A)より, 睡眠導 入時間に関しては，レンドルミン ${ }^{\circledR}$ (先発医薬品） に比へ，後発医薬品 H, J, N, R, I, K, L, S, T で遅延 が有意に認められた。睡眠持続時間については，先 発医薬品と比較し，全部の後発医薬品で時間短縮が 有意に認められた $(p<0.01)$ 。中でも，後発医薬品 I, N, S は先発医薬品と比較し, 睡眠持続時間が $1 / 2$ 以下と顕著であった。また，後発医薬品 $\mathrm{I}$ は 1 例, 睡眠を起こしていなかった。

区画移動数の結果（Fig. 3(B)）においても，先 発医薬品と比較し，観察時間を通して自発運動の抑 制が悪く，完全に自発運動が消失する時間は短くな つていた。 また, 後発医薬品 $\mathrm{K}, \mathrm{L}, \mathrm{M}, \mathrm{O}, \mathrm{P}, \mathrm{Q}, \mathrm{R}$, $\mathrm{T}$ については先発医薬品と比較して, 自発運動の回 復が早いことが確認された (Fig. 3(B) 4 時間後).

\section{2-2. 投与後 1 時間の血中濃度の比較 先発医} 薬品之後発医薬品 $(\mathrm{H}-\mathrm{T})$ 投与 1 時間後の血中濃 度の結果を Fig. 3(C) に示した。先発医薬品の血中 濃度を $100 \%$ で表したときの後発医薬品（H-T）の 血中濃度を比で表している。後発医薬品 $\mathrm{H}$ は $45 \%$, I は $63 \%$ ，J は $91 \% ， \mathrm{~K}$ は $30 \% ， \mathrm{~L}$ は $50 \% ， \mathrm{M}$ は 44\%，Nは17\%，Oは34\%，Pは21\%，Qは 9\%， $\mathrm{R}$ は $11 \%, \mathrm{~T}$ は $64 \%$ と，ほとんどの後発医薬品は 先発医薬品と比較して血中濃度が低くなっていた. また, 後発医薬品 $\mathrm{S}$ は先発医薬品とほとんど差は 認められなかった。

\section{2-3. 主成分含有量の比較 Figure 3(D) に先} 発医薬品と後発医薬品 $(\mathrm{H}-\mathrm{T})$ の主成分含有量を 比で示した。ほとんどの後発医薬品は先発医薬品と 差はみられなかつたが，規格内でのばらつきを考慮 に入れても $\mathrm{O}$ は $77 \%$ と，先発医薬品と比較してや や低めであった。

これらの結果から, Brotizolam 含有薬剤の後発 医薬品は，有効成分の含有量が，数製品以外では, 先発医薬品とほぼ同じであるにも係わらず，先発医 薬品と比へ，薬効や投与後 1 時間の血中濃度が低め であった。このことから，主成分の含有量が同一で も，吸収や作用の発現に差が出る可能性が示唆され
る.

\section{Flunitrazepam 含有薬剤}

3-1. 薬効の比較 Figure 4(A)より, 睡眠導 入時間に関しては，サイレース ${ }^{\circledR}$ (先発医薬品）と 比較し, すべての後発医薬品に差は認められなかつ た。しかし，睡眠持続時間については若干ではある が, 先発医薬品に比べ, 後発医薬品 $\mathrm{U}(p<0.05)$, Wで時間短縮が認められた。

先発医薬品と比較し, 後発医薬品 $\mathrm{W}$ にのみ, 自 発運動の抑制発現の遅延傾向が認められ（Fig. 4(B) 1 時間後), 全後発医薬品について, 自発運動の回 復は早いことが確認された（Fig. 4(B) 5 時間後).

\section{3-2. 投与後 1 時間の血中濃度の比較 先発医} 薬品と後発医薬品 $(\mathrm{U}-\mathrm{W})$ 投与 1 時間後の血中濃 度を先発医薬品の血中濃度を $100 \%$ として Fig. 4 (C) に示した。後発医薬品 $\mathrm{V}$ は先発医薬品と差がみ られなかったが，後発医薬品U は $70 \% ， W$ は 86 $\%$ と先発医薬品と比較して血中濃度が低い傾向があ つた.

3-3. 主成分含有量の比較 先発医薬品と後発 医薬品 (U-W) の主成分含有量を，先発医薬品の 主成分含有量を $100 \%$ として示した（Fig. 4(D)). 規格内でのばらつきを考慮に入れると，後発医薬品 すべてにおいて先発医薬品とほぼ同等であった。

これらの結果から, Flunitrazepam 含有後発医薬 品は，先発医薬品と比へ，睡眠持続時間がやや短め であり, 自発運動の回復も早めであった.

\section{考察}

各含有薬剤での結果のまとめを Table 1 に示す. これらの結果から，主成分含有量が先発医薬品と同 等にも係わらず，投与 1 時間後の血中濃度や睡眠導 入時間，睡眠持続時間に差が現れており，後発医薬 品は, 先発医薬品と薬効, 血中濃度の推移がかなら ずしも一致しないことが明らかとなった。また，各 薬剂間における薬効の違いは，主成分含有量の違い によるものもあるが，ほとんどが血中濃度に起因す ると考えられる．これらのことから，後発医薬品は 先発医薬品と同等と扱われているにも係わらず，製 品それぞれにおいて薬物動態の違いが存在する可能 性が示唆された。また，後発医薬品間にも薬効や血 中濃度の差が認められたことから，製品間で医薬品 の性質の違いが存在することが考えられる。 
(A) Onset time and duration of sleep

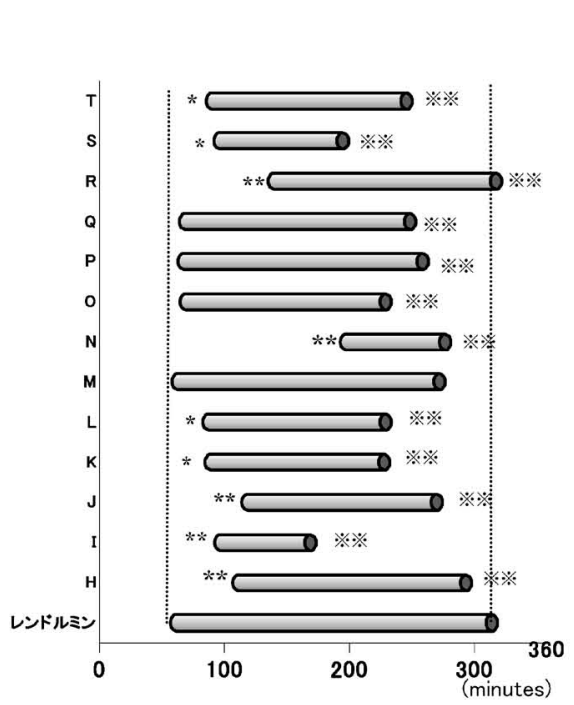

\begin{tabular}{|c|c|c|}
\hline & $\begin{array}{c}\text { 睡眠導入時間 } \\
\text { (minutes） }\end{array}$ & $\begin{array}{c}\text { 睡眠持続時間 } \\
\text { (minutes） }\end{array}$ \\
\hline $\begin{array}{c}\text { レンドルミン® } \\
\quad(n=5)\end{array}$ & $50.2 \pm 2.6$ & $252.8 \pm 18.5$ \\
\hline $\mathrm{H} \quad(\mathrm{n}=4)$ & $100.0 \pm 4.7^{* *}$ & $182.3 \pm 15.4 \% *$ \\
\hline I $\quad(n=4)$ & $85.5 \pm 5.5^{\star *}$ & $72.3 \pm 15.8 \% \%$ \\
\hline $\mathbf{J}(n=4)$ & $107.5 \pm 8.8^{* *}$ & $151.3 \pm 4.8 * *$ \\
\hline$K \quad(n=3)$ & $77.7 \pm 9.3^{*}$ & $139.0 \pm 29.9 \% \approx$ \\
\hline$L \quad(n=4)$ & $76.0 \pm 5.8^{*}$ & $141.8 \pm 26.0 \%$ \\
\hline$M \quad(n=3)$ & $51.3 \pm 3.2$ & $209.7 \pm 28.4 \%$ \\
\hline$N(n=3)$ & $186.0 \pm 1.5^{* *}$ & $79.3 \pm 0.9 \approx *$ \\
\hline$O(n=5)$ & $58.0 \pm 9.8$ & $159.6 \pm 18.5 \% \%$ \\
\hline$P \quad(n=4)$ & $56.0 \pm 9.2$ & $191.5 \pm 10.9 \% \%$ \\
\hline$Q(n=3)$ & $57.0 \pm 2.8$ & $180.3 \pm 10.8 \% *$ \\
\hline$R \quad(n=5)$ & $128.4 \pm 17.9^{* *}$ & $177.6 \pm 17.5 \approx *$ \\
\hline$S(n=5)$ & $85.2 \pm 15.6^{*}$ & $98.0 \pm 17.7 \approx *$ \\
\hline$T(n=3)$ & $78.7 \pm 17.9^{*}$ & $156.0 \pm 20.8 \% *$ \\
\hline
\end{tabular}

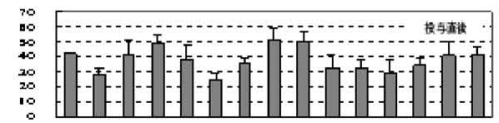

(C) Serum concentration
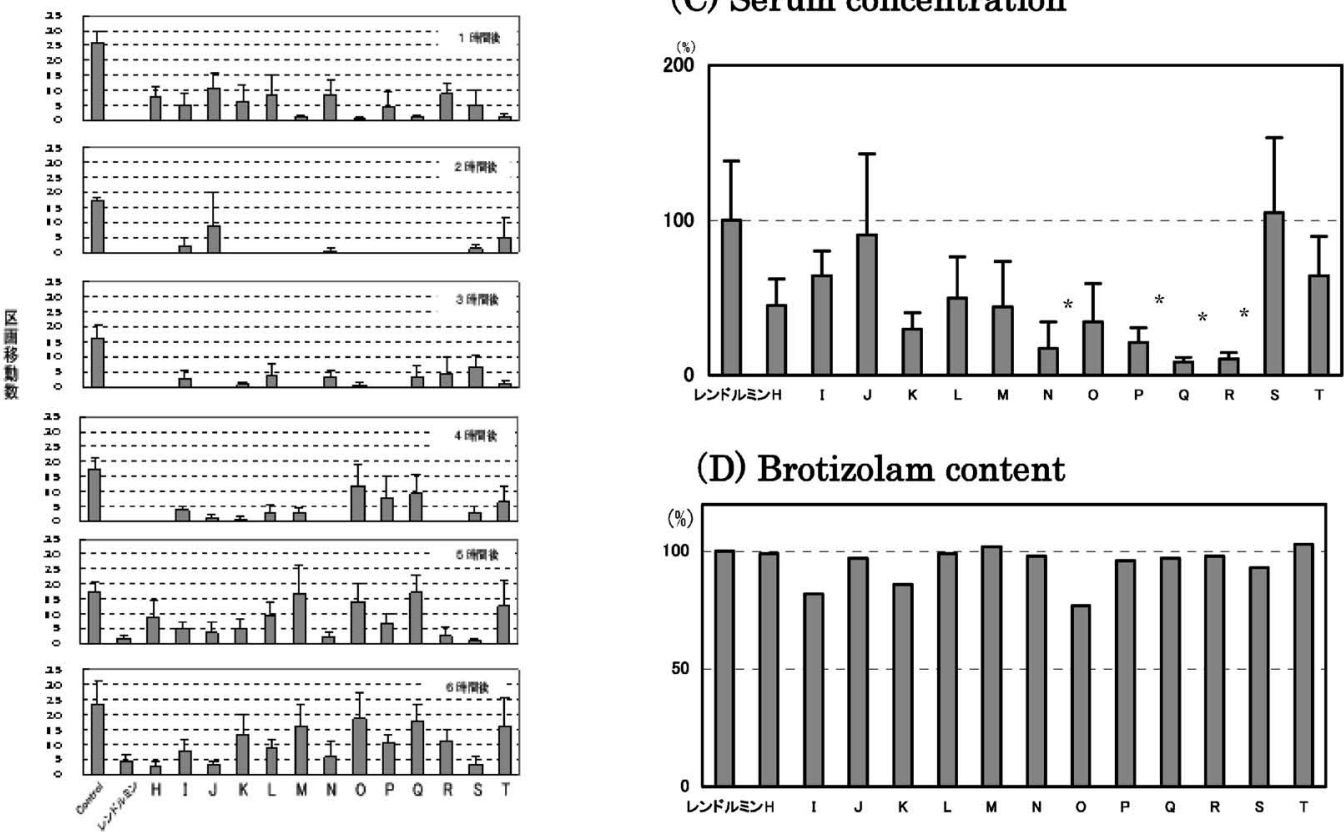

(D) Brotizolam content

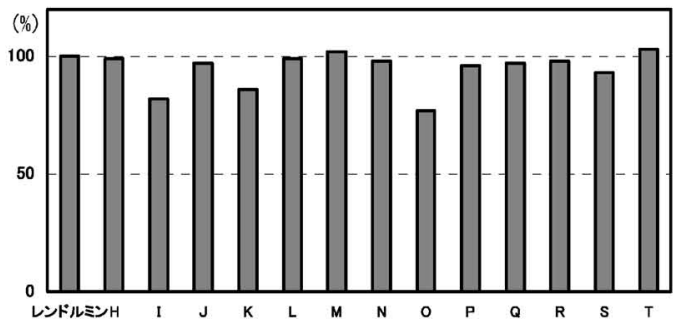

Fig. 3. Experimental Results of Brotizolam Containing Drugs

A) : Comparison of onset time of sleep and duration of sleep induced with original or generic drugs containing brotizolam mainly. The graph's bar means onset time of sleep after oral administration and the length means duration of sleeps. These results were shown as mean. Results in the table are expressed as means \pm S.E. ※: Significantly different from レンドルミン group $(p<0.01)$. *, ※: Significantly different from レンドルミン group $(p<0.05)$. (A mouse in group I did not sleep). B) : Change over time of ambulation after administration of brotizolam containing drugs. Results are expressed as means \pm S.E. C) : Serum concentration of brotizolam 1 hour after administration of original or generic drugs. Results are expressed as means \pm S.E. of three mice. *Significantly different from レンドルミン

${ }^{\circledR}$ group $(p<0.05)$. D) : Comparison of brotizolam content between original and generic drugs.

また，今回の結果から，これらの違いの原因の 1 つとして, 主成分以外の成分が考えられる. 添加物 の違いや製剤条件の違いによって，生体内における
薬物の溶け方や吸収の仕方が異なれば薬効上にも差 が生じ得る。このような添加物の違いによる吸収速 度や効果の差は懸念されており，例えば，フェニト 
(A) Onset time and duration of sleep

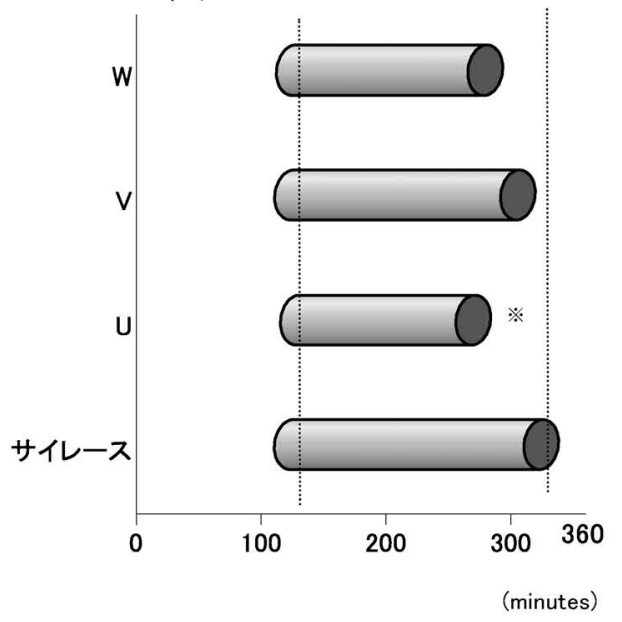

\begin{tabular}{|c|c|c|}
\hline & $\begin{array}{c}\text { 睡眠導入時間 } \\
(\text { minutes })\end{array}$ & $\begin{array}{c}\text { 睡眠持続時間 } \\
\text { (minutes) }\end{array}$ \\
\hline $\begin{array}{c}\text { サイレース® } \\
(\mathrm{n}=4)\end{array}$ & $90.0 \pm 8.1$ & $199.8 \pm 20.9$ \\
\hline $\mathrm{U}(\mathrm{n}=3)$ & $94.7 \pm 6.2$ & $140.5 \pm 16.3 \%$ \\
\hline $\mathrm{V}(\mathrm{n}=3)$ & $90.3 \pm 31.5$ & $180.7 \pm 14.4$ \\
\hline $\mathrm{W}(\mathrm{n}=3)$ & $91.7 \pm 11.7$ & $153.3 \pm 23.3$ \\
\hline
\end{tabular}

(B) Ambulation

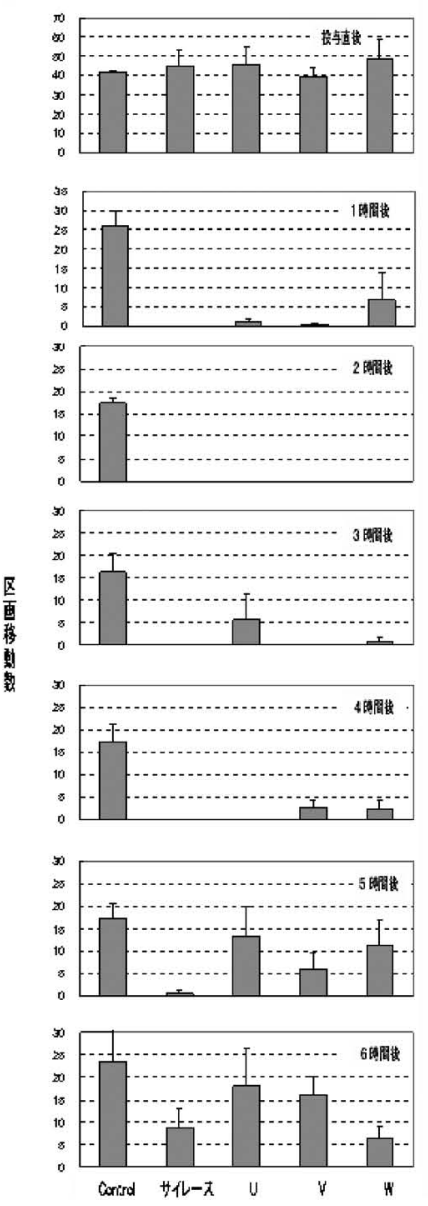

\section{(C) Serum concentration}

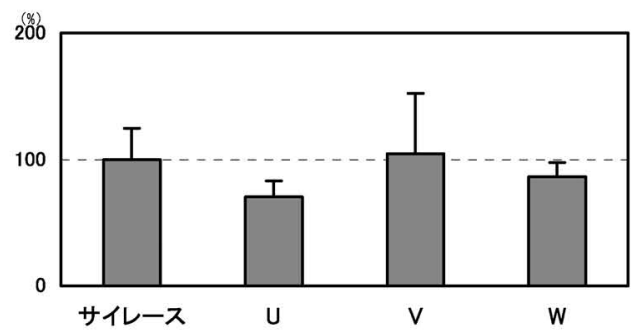

(D) Flunitrazepam content

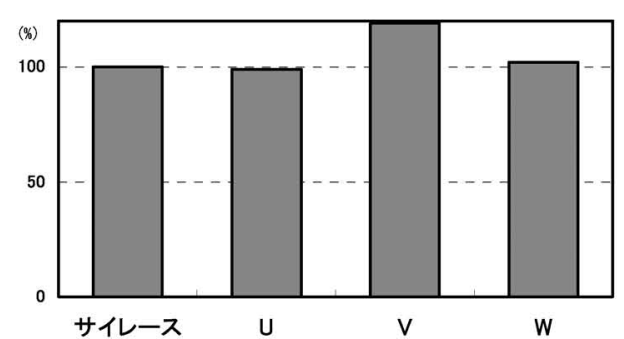

Fig. 4. Experimental Results of Flunitrazepam Containing Drugs

A) : Comparison of onset time of sleep and duration of sleep induced with original or generic drugs containing flunitrazepam mainly. The graph's bar means onset time of sleep after oral administration and the length means duration of sleeps. These results were shown as mean. Results in the table are expressed as means \pm S.E. ※: Significantly different from サイレース ${ }^{\circledR}(p<0.05)$. B): Change over time of ambulation after administration of flunitrazepam containing drugs. Results are expressed as means \pm S.E. C) : Serum concentration of flunitrazepam 1 hour after administration of original or generic drugs. Results are expressed as means \pm S.E. of three mice. D) : Comparison of flunitrazepam content between original and generic drugs.

インカプセルによる薬物中毒は, 添加物の種類や量 の違いが原因となり，血中濃度に差が現れた例であ る. 10) 本研究で認められた薬効差の原因としても,
医薬品添加物，主薬の結晶形，製剂等の違いが考え られるが，製剤による吸収差は，特殊コーティング の施されていない薬剂を乳鉢で微粉砕して投与する 
Table 1. The Comparative Results of Efficucy between Generic Drugs and Original Drugs

A）Triazolam 含有薬剂

\begin{tabular}{ccccc}
\hline \hline $\begin{array}{c}\text { 後発 } \\
\text { 医薬品 }\end{array}$ & $\begin{array}{c}\text { 睡眠導 } \\
\text { 入時間 }\end{array}$ & $\begin{array}{c}\text { 睡眠持 } \\
\text { 続時間 }\end{array}$ & $\begin{array}{c}\text { 投与 1 時間後 } \\
\text { の血中濃度 }\end{array}$ & $\begin{array}{c}\text { 主成分 } \\
\text { 含有量 }\end{array}$ \\
\hline $\mathrm{A}$ & $\downarrow \downarrow$ & \pm & $\searrow$ & \pm \\
\hline $\mathrm{B}$ & \pm & $\nearrow$ & $\nearrow$ & \pm \\
\hline $\mathrm{C}$ & \pm & $\uparrow$ & \pm & \pm \\
\hline $\mathrm{D}$ & $\searrow$ & $\downarrow \downarrow$ & \pm & \pm \\
\hline $\mathrm{E}$ & $\uparrow \uparrow$ & $\searrow$ & $\uparrow$ & $\searrow$ \\
\hline $\mathrm{F}$ & \pm & \pm & $\nearrow$ & \pm \\
\hline $\mathrm{G}$ & \pm & $\downarrow$ & \pm & \pm \\
\hline
\end{tabular}

B) Brotizolam 含有薬剂

\begin{tabular}{ccccc}
\hline \hline $\begin{array}{c}\text { 後発 } \\
\text { 医楽品 }\end{array}$ & $\begin{array}{c}\text { 睡眠噵 } \\
\text { 入時 }\end{array}$ & $\begin{array}{c}\text { 睡眠持 } \\
\text { 続時間 }\end{array}$ & $\begin{array}{c}\text { 投与 } 1 \text { 時間後 } \\
\text { の血中濃度 }\end{array}$ & $\begin{array}{c}\text { 主成分 } \\
\text { 含有量 }\end{array}$ \\
\hline $\mathrm{H}$ & $\downarrow \downarrow$ & $\downarrow \downarrow$ & $\searrow$ & \pm \\
\hline $\mathrm{I}$ & $\downarrow \downarrow$ & $\downarrow \downarrow$ & $\searrow$ & \pm \\
\hline $\mathrm{J}$ & $\downarrow \downarrow$ & $\downarrow \downarrow$ & $\searrow$ & \pm \\
\hline $\mathrm{L}$ & $\downarrow$ & $\downarrow \downarrow$ & $\searrow$ & \pm \\
\hline $\mathrm{M}$ & \pm & $\downarrow \downarrow$ & $\downarrow$ & \pm \\
\hline $\mathrm{N}$ & $\downarrow \downarrow$ & $\downarrow \downarrow$ & $\searrow$ & \pm \\
\hline $\mathrm{O}$ & \pm & $\downarrow \downarrow$ & $\downarrow$ & \pm \\
\hline $\mathrm{P}$ & \pm & $\downarrow \downarrow$ & $\downarrow$ & \pm \\
\hline $\mathrm{Q}$ & \pm & $\downarrow \downarrow$ & $\downarrow$ & \pm \\
\hline $\mathrm{R}$ & $\downarrow \downarrow$ & $\downarrow \downarrow$ & $\searrow$ & \pm \\
\hline $\mathrm{S}$ & $\downarrow$ & $\downarrow \downarrow$ & $\downarrow$ & \pm \\
\hline $\mathrm{T}$ & $\downarrow$ & $\downarrow \downarrow$ & & $\searrow$ \\
\hline
\end{tabular}

C) Flunitrazepam 含有薬剂

\begin{tabular}{|c|c|c|c|c|}
\hline $\begin{array}{l}\text { 後発 } \\
\text { 医薬品 }\end{array}$ & $\begin{array}{l}\text { 睡眠䆃 } \\
\text { 入時間 }\end{array}$ & $\begin{array}{l}\text { 睡眠持 } \\
\text { 続時間 }\end{array}$ & $\begin{array}{c}\text { 投与 } 1 \text { 時間後 } \\
\text { の血中濃度 }\end{array}$ & $\begin{array}{l}\text { 主成分 } \\
\text { 含有量 }\end{array}$ \\
\hline $\mathrm{U}$ & \pm & $\downarrow$ & $\searrow$ & \pm \\
\hline $\mathrm{V}$ & \pm & \pm & \pm & \pm \\
\hline W & \pm & $\searrow$ & \pm & \pm \\
\hline \multicolumn{5}{|c|}{ 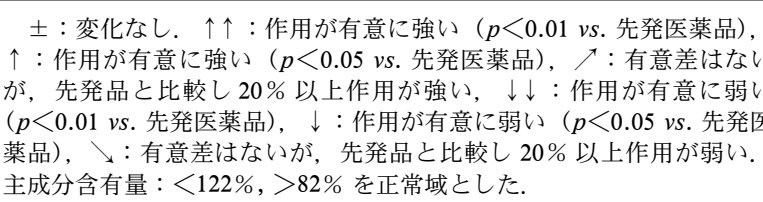 } \\
\hline
\end{tabular}

実験系であるため，考え難い。そこで，添加物を， 添付文書（添付文書に記載のない医薬品はインタビ ューフォーム）より一覧にし比較検討した（Table
2).その結果，いくつかの添加物は異なつているこ とが明らかとなった。

Triazolam 含有薬剂では，含量が先発品と同等で あったにも係わらず，睡眠の導入時間が特に遅延 し，投与後 1 時間の血中濃度も低濃度であった後発 医薬品 A は，Table 2-A) よりクエン酸カルシウム が含まれているが，他の製品には含まれていない． クエン酸カルシウムは難溶性であるが構造中にカル ボン酸を有するため，体内の $\mathrm{pH}$ によっては弱塩基 となった triazolam とインターラクションを起こ し，薬物吸収，薬効に影響を与えている可能性が考 えられる，次に，brotizolam 含有薬剤でも，睡眠導 入時間の大きな遅延が認められた後発医薬品 $N, R$ は, Table 2-B)より，硬化油が含まれているのに対 し, 先発医薬品や他の後発医薬品にはステアリン酸 マグネシウムが含まれている。硬化油は脂肪油に水 素を添加して得た油であり, ${ }^{11)}$ 滑沢剂として用いら れていると考えられるが，薬物粒子表面に付着した 滑沢剂は撥水性を示し，主薬の溶出に遅延を招く可

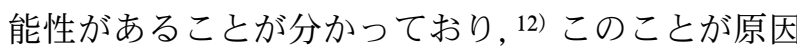
となって薬物の溶出や吸収に違いを引き起こし，薬 効に影響を及ぼしている可能性が考えられる.

医薬品添加物について調べた結果，医薬品添加物 の用量表示はなされていないために，その詳細を知 ることは困難であった。 さらに，後発医薬品 N, R は含有されている添加物は同じであるにも係わら ず，薬効では若干の差が観察された．添加物以外の 違いが存在する可能性も考えられるが，添加物の用 量の違いから起きている可能性も存在する.

本研究では, 医薬品添加物に関する情報の少なさ ゆえに，医薬品添加物によって引き起こされる相互 作用を知ることは困難であった。 今後，より充実し た薬物治療のためには，医薬品添加物に関する情報 がより多く公開されることが必須であると考えられ る.

\section{ま と め}

本研究では, 懸念されている後発医薬品と先発医 薬品の同等性について動物実験を行い，同等性が証 明されれば，医師や薬剤師が安心して後発医薬品を 奨められるのではないかと考え，催眠鎮静剂 (Triazolam 含有薬剤, Brotizolam 含有薬剂, Flunitrazepam 含有薬剤）を用いて同等性の比較検討を 
Table 2. Containing Drug Additives in Each Drugs

A） Triazolam 含有薬剤に含有される医薬品添加物

\begin{tabular}{|c|c|c|c|c|c|c|c|c|c|c|c|c|c|c|c|c|c|c|c|c|c|c|}
\hline $\mathrm{O} / \mathrm{G}$ & 品名 & 製薬会社 & 一般名 & 用途 & $\begin{array}{l}\text { 剂 } \\
\text { 形 }\end{array}$ & $\begin{array}{l}\text { 乳 } \\
\text { 糖 }\end{array}$ & $\begin{array}{l}\text { トン } \\
\text { ウプ } \\
\text { モン } \\
\text { ロ } \\
\text { コ } \\
\text { デ }\end{array}$ & $\begin{array}{l}\text { 部华 } \\
\text { 分デ } \\
\text { ルプ } \\
\text { フン } \\
\text { ア } \\
1\end{array}$ & $\begin{array}{l}\text { 結 } \\
\text { 檪 } \\
\text { J } \\
\text { 口 } \\
\text { ス } \\
\text { ス }\end{array}$ & $\begin{array}{l}\text { ヒピ } \\
\text { ドル } \\
\text { ロセ } \\
\text { キル } \\
\text { シロ } \\
\text { プl } \\
\text { ロス }\end{array}$ & $\begin{array}{l}\text { セ } \\
\text { ル } \\
\text { ㅁ } \\
\text { I } \\
\text { ス }\end{array}$ & $\begin{array}{l}\text { 六 } \\
\bar{\sigma} \\
\text { J } \\
\text { リ } \\
\dot{3} \\
\text { 酸 } \\
\mathrm{Mg}\end{array}$ & $\begin{array}{l}\text { ク } \\
\text { I } \\
\text { 酸 } \\
\mathrm{Ca}\end{array}$ & $\begin{array}{l}\text { 蒠 } \\
\text { 香 } \\
\text { 酸 } \\
\mathrm{Na}\end{array}$ & $\begin{array}{l}\text { 軽 } \\
\text { 椞 } \\
\text { 無 } \\
\text { 水 } \\
\text { ケ } \\
\text { 1 } \\
\text { 酸 }\end{array}$ & $\begin{array}{l}\text { 低キル } \\
\text { 置シロロ } \\
\text { 換プ I } \\
\text { 度ロス } \\
\text { ヒピ } \\
\text { ドル } \\
\text { ロセ }\end{array}$ & $\begin{array}{l}\text { 酸 } \\
\text { 华 } \\
5 \\
1 \\
\text { 素 }\end{array}$ & $\begin{array}{l}\text { ジウシ } \\
\text { オム永 } \\
\text { クス } \\
\text { チルト } \\
\text { ルホ } \\
\text { ソササ } \\
\text { ジク }\end{array}$ & $\begin{array}{l}\text { ク } \\
\text { 口ス } \\
\text { 弪 } \\
\text { 力 } \\
\text { ル } \\
\text { メ } \\
\text { 口 }\end{array}$ & $\begin{array}{ll} & \\
\text { 青 } \\
\text { 青 } \\
\text { 1 } \\
\text { 号 } \\
\text { 号 }\end{array}$ & 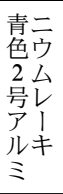 & $\begin{array}{l}\text { 赤 } \\
\text { 3 } \\
\text { 号 }\end{array}$ \\
\hline $\mathrm{O}$ & ハルシオン & ファイザー & トリアゾラム & 催眠鎮静 & $\mathrm{T}$ & 0 & ○ & & 0 & & & 0 & & 0 & 0 & & & 0 & & & 0 & \\
\hline G & A & $\mathrm{A}^{\prime}$ & & & $\mathrm{T}$ & O & 0 & & & O & 0 & 0 & 0 & & & & & & & & & \\
\hline G & B & $\mathrm{B}^{\prime}$ & & & $\mathrm{T}$ & O & 0 & & 0 & O & & 0 & & & & & & & & & & \\
\hline G & $\mathrm{C}$ & $\mathrm{C}^{\prime}$ & & & $\mathrm{T}$ & 0 & 0 & & & 0 & 0 & 0 & & 0 & & 0 & 0 & 0 & & 0 & & \\
\hline G & D & $\mathrm{D}^{\prime}$ & & & $\mathrm{T}$ & 0 & 0 & & 0 & 0 & & 0 & & & 0 & & & & & 0 & & \\
\hline G & $\mathrm{E}$ & $\mathrm{E}^{\prime}$ & & & $\mathrm{T}$ & 0 & 0 & 0 & & 0 & & 0 & & & & & & & & & & \\
\hline G & $\mathrm{F}$ & $\mathrm{F}^{\prime}$ & & & $\mathrm{T}$ & 0 & 0 & & & 0 & 0 & 0 & & & & & & & & & 0 & \\
\hline G & G & $\mathrm{G}^{\prime}$ & & & $\mathrm{T}$ & 0 & 0 & & 0 & 0 & & 0 & & & & & & & 0 & 0 & & 0 \\
\hline
\end{tabular}

B） brotizolam 含有薬剂に含有される医薬品添加物

\begin{tabular}{|c|c|c|c|c|c|c|c|c|c|c|c|c|c|c|c|c|c|c|c|c|c|}
\hline $\mathrm{O} / \mathrm{G}$ & 品名 & 製薬会社 & 一般名 & 用途 & $\begin{array}{l}\text { 剂 } \\
\text { 形 }\end{array}$ & $\begin{array}{l}\text { 乳 } \\
\text { 糖 }\end{array}$ & $\begin{array}{l}\text { トン } \\
\text { ウプ } \\
\text { モ̇ン } \\
\text { ロ } \\
\text { シ } \\
\text { デ }\end{array}$ & $\begin{array}{l}\text { 部化 } \\
\text { 分デ } \\
\text { ルプ } \\
\text { フンン } \\
\text { ア } \\
1\end{array}$ & $\begin{array}{l}\text { 結 } \\
\text { 晶 } \\
\text { セ } \\
\text { ル } \\
\text { 口 } \\
\text { l } \\
\text { ス }\end{array}$ & $\begin{array}{l}\text { ヒピ } \\
\text { ドル } \\
\text { ロセ } \\
\text { キル } \\
\text { シ。 } \\
\text { プ } \\
\text { ロス }\end{array}$ & $\begin{array}{l}\text { セ } \\
\text { ル } \\
\text { 口 } \\
\text { ス } \\
\text { ス }\end{array}$ & 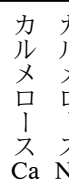 & 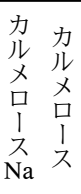 & 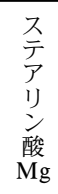 & 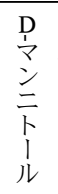 & $\begin{array}{ll} & \\
\text { ゼ } & \text { 夕 } \\
\text { チ } & \text { 多 } \\
\text { ン } & \end{array}$ & 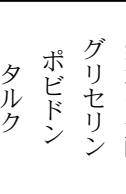 & 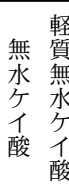 & 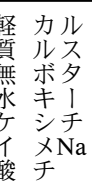 & 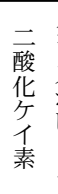 & 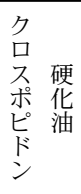 \\
\hline $\mathrm{O}$ & レンドルミン & ベーリンガー & ブロチゾラム & 催眠鎮静 & $\mathrm{T}$ & 0 & $\bigcirc$ & & 0 & & & & & 0 & 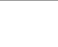 & O & & & 0 & & \\
\hline G & $\mathrm{H}$ & $\mathrm{H}^{\prime}$ & & & $\mathrm{T}$ & $\bigcirc$ & & & 0 & $\bigcirc$ & & & & 0 & & & $\bigcirc$ & & & & $\bigcirc$ \\
\hline G & I & $I^{\prime}$ & & & $\mathrm{T}$ & 0 & $\bigcirc$ & & & O & & & & 0 & & & & ○ & $\bigcirc$ & & \\
\hline G & $\mathrm{J}$ & $\mathrm{J}^{\prime}$ & & & $\mathrm{T}$ & 0 & & & $\bigcirc$ & & & & 0 & $\bigcirc$ & & & O & & & & \\
\hline G & $\mathrm{K}$ & $\mathrm{K}^{\prime}$ & & & $\mathrm{T}$ & 0 & $\bigcirc$ & & & O & & & & ○ & & & & 0 & O & & \\
\hline G & $\mathrm{L}$ & $\mathrm{L}^{\prime}$ & & & $\mathrm{T}$ & 0 & & & & $\bigcirc$ & $\bigcirc$ & $c$ & O & $\bigcirc$ & & & & & & & \\
\hline G & M & $\mathrm{M}^{\prime}$ & & & $\mathrm{T}$ & 0 & $\bigcirc$ & & & 0 & $\bigcirc$ & & & 0 & & & & & 0 & 0 & \\
\hline G & $\mathrm{N}$ & $\mathrm{N}^{\prime}$ & & & $\mathrm{T}$ & 0 & & $\bigcirc$ & 0 & 0 & & & & & & & & & & & 0 \\
\hline G & $\mathrm{O}$ & $\mathrm{O}^{\prime}$ & & & $\mathrm{T}$ & 0 & $\bigcirc$ & & $\bigcirc$ & O & & & & $\bigcirc$ & & & & & & & \\
\hline G & $\mathrm{P}$ & $\mathrm{P}^{\prime}$ & & & $\mathrm{T}$ & 0 & 0 & & & 0 & $\bigcirc$ & & & 0 & & & 0 & & & & \\
\hline G & Q & $Q^{\prime}$ & & & $\mathrm{T}$ & & & & & & & & & 0 & $\bigcirc$ & & & O & & & O \\
\hline G & $\mathrm{R}$ & $\mathrm{R}^{\prime}$ & & & $\mathrm{T}$ & 0 & & $\bigcirc$ & 0 & 0 & & & & & & & & & & & 0 \\
\hline G & $\mathrm{S}$ & $S^{\prime}$ & & & $\mathrm{T}$ & & & $\bigcirc$ & 0 & & & & & 0 & 0 & & 0 & 0 & b & & \\
\hline G & $\mathrm{T}$ & $\mathrm{T}^{\prime}$ & & & $\mathrm{T}$ & 0 & $\bigcirc$ & & 0 & & & & & 0 & & & 0 & & & & \\
\hline
\end{tabular}

C） Flunitrazepam 含有薬剂に含有される医薬品添加物

\begin{tabular}{|c|c|c|c|c|c|c|c|c|c|c|c|c|c|}
\hline $\mathrm{O} / \mathrm{G}$ & 品名 & 製薬会社 & 一般名 & 用途 & $\begin{array}{l}\text { 剂 } \\
\text { 形 }\end{array}$ & $\begin{array}{l}\text { 乳 } \\
\text { 糖 }\end{array}$ & $\begin{array}{l}\text { 結 } \\
\text { 晶 } \\
\text { セ } \\
\text { ル } \\
\text { 口 } \\
\text { I } \\
\text { ス }\end{array}$ & $\begin{array}{l}\text { ヒピ } \\
\text { ドル } \\
\text { ロセ } \\
\text { キル } \\
\text { ジロ } \\
\text { プ I } \\
\text { ロス }\end{array}$ & $\begin{array}{l}セ \\
\text { ル } \\
\text { 口 } \\
\text { ス }\end{array}$ & 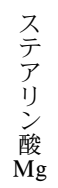 & $\begin{array}{l}\text { 多 } \\
\text { 少 }\end{array}$ & $\begin{array}{l}\text { 低キル } \\
\text { 置シロ } \\
\text { 換プ I } \\
\text { 度ロス } \\
\text { ヒピ } \\
\text { ドル } \\
\text { ロセ }\end{array}$ & $\begin{array}{l}\text { 云 } \\
\text { 酸 } \\
\text { 华 } \\
\text { 年 } \\
\text { 素 } \\
\text { 素 }\end{array}$ \\
\hline $\mathrm{O}$ & サイレース & エーザイ & フルニトラゼパム & 催眠鎮静 & $\mathrm{T}$ & O & O & & & 0 & $\bigcirc$ & & \\
\hline G & $\mathrm{U}$ & $\mathrm{U}^{\prime}$ & & & $\mathrm{T}$ & O & & & 0 & O & O & $\bigcirc$ & O \\
\hline G & $\mathrm{V}$ & $\mathrm{V}^{\prime}$ & & & $\mathrm{T}$ & 0 & & 0 & 0 & 0 & $\bigcirc$ & & 0 \\
\hline G & $\mathrm{W}$ & $\mathrm{w}^{\prime}$ & & & $\mathrm{T}$ & 0 & 0 & & & 0 & 0 & & \\
\hline
\end{tabular}

O: Original drug, G: Generic drug, T: Tablet. 
行った。また，同一主成分を含有する医薬品間での 添加物の違いに着目し, 医薬品添加物の成分を比較 検討した.

本研究の結果，同等性を示す後発医薬品も示さな い後発医薬品も存在した。しかし，この結果は動物 実験によるものであり，その投与量から先発医薬品 と後発医薬品の薬効差は，ヒトよりも大きく現れる と考えられる。自発運動である程度，同様な傾向を 示した製品は，ヒトで同等性が示される可能性は高 いと考えられるが，かならずしも動物実験の結果が ヒトで反映されるとも限らない。

本研究より，先発医薬品と後発医薬品は，主成分 と含量が同一であっても含有される添加物は同一で ないため，薬効や吸収に影響を及ぼす可能性が示唆 された．医薬品を選択する際には，医薬品添加物に ついても考察する必要性が考えられ，今後，医薬品 添加物の情報を充実させることは急務であると考え られる。

将来的には患者自身が治療薬を選択し，不安なく 服用できるよう，後発医薬品に関する情報がより分 かり易く充実して提供されることが望まれる.

謝辞薬剤の提供をいただきました各製薬会 社，及び実験動物の飼育をしていただきました広島 大学自然科学研究支援開発センター生命科学研究支 援分野ライフサイエンス教育研究支援部（動物実験 施設）に感謝申し上げます。

\section{REFERENCES}

1) Koguma K., Takai T., Sakai H., "Yousyu- tusiken niyoru Iryouyou Kouhatuiyakuhin no Hinnsitutyousa," Niigatakenhokenkankyoukagaku-kennkyuusyonenpou, 17 (2002) .

2) Takai T., Higuchi R., Koguma K., Sakai H., "Yousyutusiken niyoru Iryouyou Kouhatuiyakuhin no Hinnsitutyousa (No. 2)," Niigatakenhokenkankyou-kagakukennkyuusyonenpou, 18 (2003).

3) Shuukannigakukaishinbun, "Kouhatuiyakuhin wo Sodateru Fuanwo Shinraini Kaerutameni,"' Igakushoin (2591, date 2004.07.05).

4) Kimishima K., Tanabe K., Kinoshita Y., Tamaki H., Kawamura M., Kurihara A., J. Yonago Med. Association, 27, 314-323 (1976).

5) Ueki S., Watanabe S., Yamamoto T., Shibata S., Shibata K., Jpn. J. Pharmacol., 35, 287299 (1984).

6) Yajima T., Oyo Yakuri, 21, 123 (1981).

7) Hall C. S., J. Comp. Physiol., 22, 345 (1936).

8) Kuhn F. J., Br. J. Clin. Pharmacol., 16, 253260 (1983).

9) Amini H., Ahmadiani A., J. Chromatogr. B, 809, 227-230 (2004).

10) Inoue T., "Iyakuhintenkabutuno Genjyouto Mondaiten Shinseizaikaihatu System Sougougijyutu -Kizai - Tenkabutuhen-," R\&D Planning, 1985, pp. 365-409.

11) “Iyakuhintenkabutujiten $2000, "$ ed. by $\mathrm{Ni}$ honiyakuhintenkazaikyoukai, Yakujinipousya.

12) Uekama K., Kawashima Y., "Saishinseizaigaku,” Hirokawashoten, 2000, pp. 339-384. 